\title{
Functional Expression of Cf9 and Avr9 Genes in Brassica napus Induces Enhanced Resistance to Leptosphaeria maculans
}

\author{
Caroline Hennin, ${ }^{1}$ Monica Höfte, ${ }^{1}$ and Elke Diederichsen ${ }^{2}$ \\ ${ }^{1}$ Faculty of Agricultural and Applied Biological Sciences, Laboratory of Phytopathology, Ghent University, \\ Coupure Links 653, B-9000 Gent, Belgium; ${ }^{2}$ Aventis CropScience, J. Plateaustraat 22, B-9000 Gent, \\ Belgium \\ Submitted 14 December 2000; Accepted 17 May 2001.
}

\begin{abstract}
The tomato $C f 9$ resistance gene induces an Avr9dependent hypersensitive response (HR) in tomato and transgenic Solanaceae spp. We studied whether the $C f 9$ gene product responded functionally to the corresponding Avr9 gene product when introduced in a heterologous plant species. We successfully expressed the $C f^{9}$ gene under control of its own promoter and the Avr9 or Avr9R8K genes under control of the $\mathrm{p}^{35 \mathrm{~S}_{1}}$ promoter in transgenic oilseed rape. We demonstrated that the transgenic oilseed rape plants produced the Avr9 elicitor with the same specific necrosis-inducing activity as reported for Cladosporium fulvum. An Avr9-dependent HR was induced in $\boldsymbol{C} \boldsymbol{f} \boldsymbol{9}$ oilseed rape upon injection of intercellular fluid containing Avr9. We showed Avr9-specific induction of PR1, PR2, and $C x c 750$ defense genes in oilseed rape expressing $C f 9$. $C f 9 \times A v r 9$ oilseed rape did not result in seedling death of the $F_{1}$ progeny, independent of the promoters used to express the genes. The $\mathrm{F}_{1}(C f 9 \times$ Avr9) plants, however, were quantitatively more resistant to Leptosphaeria maculans. Phytopathological analyses revealed that disease development of $L$. maculans was delayed when the pathogen was applied on an Avr9-mediated HR site. We demonstrate that the $C f 9$ and $A v r^{9}$ gene can be functionally expressed in a heterologous plant species and that the two components confer an increase in disease resistance.
\end{abstract}

Additional keywords: defense responses, gene-for-gene concept, transgenic plants, two-component system.

Among plant defense reactions to pathogen infection, particular interest has been given to the hypersensitive response (HR). The HR is a rapid and strictly localized cell death at the infection site in the host plant, limiting the spread of the pathogen and preventing its propagation. On the basis of the gene-for-gene concept of Flor (1971), it is widely accepted that a dominant plant resistance $(R)$ gene and the corresponding dominant pathogen avirulence $(A v r)$ gene are the basic components required for a HR. The HR can be seen as an early defense response, involving a cascade of plant defense reactions such as the production of reactive oxygen species,

Corresponding author: E. Diederichsen; Telephone: +32 9235 8406; Fax: +32 9224 0694; E-mail: elke.diederichsen@aventis.com and followed by cell wall fortification, and the production of many defense-related proteins and compounds (Greenberg 1997; Hammond-Kosack and Jones 1996; Hutcheson 1998).

It is expected that artificial induction of the HR could be an important strategy to engineer a broad disease resistance in plants. The HR must be strictly regulated, however, in order to avoid the uncontrolled spread of cell death throughout the whole plant (De Wit 1992). Several approaches have been followed to artificially induce a HR in plants. Strittmatter et al. (1995) proposed a strategy on the basis of the pathogeninducible expression of a bacterial ribonuclease. Keller et al. (1999) induced a HR in transgenic tobacco plants by pathogen-induced expression of the elicitor cryptogein. Another possibility to artificially induce a HR in plants is the use of the two-component system (De Wit 1992). The induction of cell death and endogenous defense responses caused by placing an Avr gene under the control of a pathogen-inducible promoter in a genetic background carrying the corresponding $R$ gene could provide a general mechanism for engineering broad disease resistance (De Wit 1992).

The tomato $C f 9$ resistance gene and the corresponding Avr 9 avirulence gene are candidate genes that could be used in the two-component system. The $C f 9$ gene confers resistance to particular races of Cladosporium fulvum that express the corresponding avirulence gene Avr9 (De Wit 1992; HammondKosack et al. 1994). Cf9 and Avr9 genes have been cloned and characterized (Jones et al. 1994; Van den Ackerveken et al. 1992; Van den Ackerveken et al. 1993; Van Kan et al. 1991). Injection of the Avr9 peptide into leaves of $C f 9$ tomato plants induces an oxidative burst, electrolyte leakage, production of ethylene, salicylic acid (SA), pathogenesis-related (PR) proteins, and hypersensitive cell death at the injection site (Hammond-Kosack et al. 1996; May et al. 1996; Wubben et al. 1996). Moreover, the Cf9-Avr9 system has been transferred successfully to other Solanaceae spp. such as tobacco and potato (Hammond-Kosack et al. 1994; Hammond-Kosack et al. 1998; Honée et al. 1995; Honée et al. 1998).

Artificial induction of an Avr9-mediated HR in nonSolanaceous Cf9 transgenic plants might be difficult to achieve. There are several indications that the functional transfer of genes between distantly related plant families is limited (Tai et al. 1999). To date there has been only one particular case where a tomato Cf4-Avr4 gene cassette was expressed transiently in a distantly related plant species (As- 
teraceae) (Van der Hoorn et al. 2000). In our work, we investigated whether the specificity of the $C f 9-A v r 9$ interaction was retained when introduced into a distantly related plant species. To address this, we transformed the $C f 9$ and $A v r 9$ genes into oilseed rape, Brassica napus spp. oleifera L. Oilseed rape is a suitable species because of its well-established transformation protocol (De Block et al. 1989) and susceptibility to different types of pathogens. We investigated whether the $C f 9$ and $A v r 9$ genes could be functionally expressed in oilseed rape and whether the presence of their gene products induces defense responses that are effective in disease control.

\section{RESULTS}

\section{Functional expression of the tomato $C f 9$ gene and fungal $A v r^{9}$ gene in transgenic oilseed rape.}

In order to study whether the $C f 9$ and $A v r 9$ genes can be functionally expressed in oilseed rape, transgenic oilseed rape plants carrying the $C f 9, A v r 9$, or $A v r 9 R 8 K$ gene were generated. In the constructs used to transform oilseed rape, expression of the $C f 9$ gene was controlled by the $C f 9$ promoter (pCF1), whereas expression of the Avr9 or $A v r 9 R 8 K$ gene was

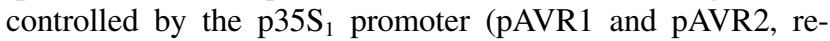
spectively). The Avr9R8K protein is a mutant Avr9 protein with higher elicitor activity in $C f 9$ tomato compared with the wild-type Avr9 protein (Kooman-Gersman et al. 1997). By including the Avr $9 R 8 K$ gene in our analyses, we were able to check whether a higher elicitor activity also could be demonstrated in $C f 9$ oilseed rape.

Northern analyses were performed to study the expression of $C f 9$ or $A v r 9-A v r 9 R 8 K$ in transgenic oilseed rape. Transcripts of the respective genes could not be detected in transgenic lines or progenies with Northern analyses. Similarly, we could not detect a $C f 9$ transcript in transgenic $C f 9$ tobacco, and only a weak $C f 9$ signal was visible in $C f 9$ tomato plants. By performing reverse transcription-polymerase chain reaction (RT-PCR) analyses with Avr9- or $C f 9$-specific primer pairs, a transcript of the expected size could be demonstrated in 11 of 13 Cf9 transformants and 17 of 18 Avr9-Avr $9 R 8 K$ oilseed rape transformants. Five hemizygous lines showing the most intense RT-PCR amplification products of the respective transgene $C f 9, A v r 9$, or $A v r 9 R 8 K$ were used in further experiments.
In $C f 9$ tomato, the injection of Avr9 elicitor results in hypersensitive cell death (Hammond-Kosack et al. 1996). We studied whether a similar phenotype occurs in $C f 9$ oilseed rape plants following Avr9 injection. Intercellular fluid (IF) from $A v r 9$ or $A v r 9 R 8 K$ oilseed rape was extracted (IF-Avr9$\mathrm{Bn}$ and IF-Avr9R8K-Bn), and two concentrations of IF were prepared: a low-concentrated IF (IF-...-1) containing 0.1 to 0.3 $\mathrm{mg}$ of crude protein per $\mathrm{ml}$ of IF and high-concentrated IF (IF...-h) containing 0.4 to $0.6 \mathrm{mg}$ of crude protein per $\mathrm{ml}$ of IF. Injection of IF-Avr9-Bn-h into $C f 9$ oilseed rape leaves induced cell death symptoms 4 to 5 days after injection (Table 1 and Fig. 1b). No cell death symptoms were observed when IF extracted from wild-type oilseed rape (IF-Wt-Bn-h or IF-WtBn-1) was injected, indicating that an Avr9-dependent HR was induced in $C f 9$ oilseed rape (Fig. 1c and d, respectively). Nevertheless, when injecting IF-Avr9-Bn-1 into $C f 9$ oilseed rape, no cell death symptoms were observed (Fig. 1a). We did not observe differences in necrosis-inducing activity between the Avr9 protein and its mutated form Avr9R8K in oilseed rape. The fluids extracted from the transgenic oilseed rape lines carrying the $A v r 9$ or the $A v r 9 R 8 K$ gene showed a similar necrosis-inducing activity. All five hemizygous lines carrying $C f 9$ reacted similarly upon Avr9 injection.

The HR phenotype observed in $C f 9$ oilseed rape after IFAvr9-Bn-h injection was confirmed histochemically using Evans blue dye, which leaks through impaired membranes and stains the content of dying cells. $C f 9$ and wild-type oilseed rape plants were injected with water, IF-Avr9-Bn-1, IF-Avr9Bn-h, IF-Wt-Bn-l, or IF-Wt-Bn-h. Injection of wild-type oilseed rape plants with all of the above-mentioned sources of IF did not induce cell death symptoms (data not shown). After injection of IF-Avr9-Bn-h in $C f 9$ oilseed rape plants, blue dye was retained in a small zone covering the IF-soaked area (Fig. 2a), indicating the induction of cell death. IF-Avr9-Bn-h injection showed a strong quantitative effect. No blue dye was retained after injection of water (Fig. 2e). Small blue dots were observed in the $C f 9$ oilseed rape leaf discs injected with IF-Avr9-Bn-1 (Fig. 2b), IF-Wt-Bn-h (Fig. 2c), or IF-Wt-Bn-1 (Fig. 2d), which were probably caused by nonspecific effects as a result of components present in the IF. Moreover, detailed microscopic investigation of the injected leaf areas did not reveal any necrotic cell death symptoms. Results were similar when Evans blue staining was performed 15, 30, 60, and 120 min after injection. All leaf discs developed a thin, dark-blue

Table 1. Days to appearance of necrosis in different plants carrying the $C f 9$ gene after injection of intercellular fluid (IF) preparations containing or lacking the Avr9 peptide

\begin{tabular}{|c|c|c|c|c|c|c|c|c|c|c|c|}
\hline & \multirow[b]{4}{*}{$\begin{array}{l}\text { Injected } \\
\text { plants }\end{array}$} & \multicolumn{10}{|c|}{ IF used for injection } \\
\hline & & \multicolumn{5}{|c|}{ Crude protein $(0.1-0.3 \mathrm{mg})$ per $\mathrm{ml}$ of IF } & \multicolumn{5}{|c|}{ Crude protein $(0.4-0.6 \mathrm{mg})$ per $\mathrm{ml}$ of IF } \\
\hline & & \multicolumn{3}{|c|}{+ Avr9 } & \multicolumn{2}{|c|}{$-\operatorname{Avr} 9$} & \multicolumn{3}{|c|}{ +Avr9 } & \multicolumn{2}{|c|}{-Avr9 } \\
\hline & & $\begin{array}{l}\text { IF-Avr9- } \\
\text { Nt-l }\end{array}$ & $\begin{array}{c}\text { IF-Avr9- } \\
\text { Bn-I }^{\mathrm{a}}\end{array}$ & $\begin{array}{c}\text { IF-Avr9R8K- } \\
\text { Bn-l }^{\mathrm{a}}\end{array}$ & $\begin{array}{c}\text { IF-Wt- } \\
\text { Nt-I }\end{array}$ & $\begin{array}{c}\text { IF-Wt- } \\
\text { Bn-I }\end{array}$ & $\begin{array}{c}\text { IF-Avr9- } \\
\text { Nt-h }\end{array}$ & $\begin{array}{c}\text { IF-Avr9- } \\
\text { Bn-h }\end{array}$ & $\begin{array}{c}\text { IF-Avr9R8K- } \\
\text { Bn-h }\end{array}$ & $\begin{array}{l}\text { IF-Wt- } \\
\text { Nt-h }\end{array}$ & $\begin{array}{c}\text { IF-Wt- } \\
\text { Bn-h }\end{array}$ \\
\hline Cf9 tobacco & 10 & $1^{\mathrm{b}}$ & 3 & 3 & $-\mathrm{b}$ & - & 1 & 3 & 3 & - & - \\
\hline Cf9 tomato & 10 & $2-3$ & $3-4$ & $3-4$ & - & - & 1 & $2-3$ & $2-3$ & - & - \\
\hline $\begin{array}{l}C f 9 \text { oilseed } \\
\text { rape }^{c}\end{array}$ & 5 & - & - & - & - & - & 3 & $4-5$ & $4-5$ & - & - \\
\hline $\begin{array}{l}\text { Wild-type } \\
\text { oilseed rape }\end{array}$ & 5 & - & - & - & - & - & - & - & - & - & - \\
\hline
\end{tabular}


ring around the perimeter of the discs, which might result from cell damage as a result of mechanical wounding. At later time points, the observation of cell death was not possible anymore, probably because the dead cells could no longer retain the dye.

Only after the injection of concentrated amounts of Avr9 elicitor cell death symptoms were observed in $C f 9$ oilseed rape, suggesting that there is a threshold level for the $C f 9_{-}$ Avr 9 response in oilseed rape. Consequently, we investigated whether a similar threshold also is present in tomato. After injection of a dilution series of Avr9-containing IF in Cf9 tomato, we observed that the more diluted the IF, the longer it took for necrotic symptoms to become visible. When injecting diluted IF-Avr9-Bn of $0.4 \times 10^{-5} \mathrm{mg}$ of protein per $\mathrm{ml}$ of IF, no necrotic symptoms were observed, indicating that, also in tomato, an Avr9 detection threshold should be reached to result in a necrotic $C f 9-A v r 9$ response. In $C f 9$ oilseed rape, however, a concentration of $0.4 \mathrm{mg}$ of protein needs to be present per $\mathrm{ml}$ of IF to induce Avr9-dependent necrosis, suggesting that the Avr9 detection threshold is $100,000 \times$ higher in oilseed rape than in tomato.

When comparing the Avr9 protein produced in transgenic Avr 9 oilseed rape with the Avr9 protein produced in transgenic $A v r 9$ tobacco, we observed that $C f 9$ oilseed rape, $C f 9$ tomato, and $C f 9$ tobacco responded faster to IF-Avr9-Nt than to either IF-Avr9-Bn or IF-Avr9R8K-Bn injections (Table 1). This observation might suggest that $i)$ the Avr9 protein from tobacco is relatively more concentrated in the IF than the Avr9 and Avr9R8K proteins from oilseed rape, ii) the Avr9 protein from tobacco is more active, or iii) this difference is the result of the absence of certain inhibitors in the IF from tobacco. To exclude the possibility that Avr9 inhibitors are present in the IF of oilseed rape, IF-Avr9-Nt was mixed with IF-Wt-Bn in a 1:1 ratio. As a control, a 1:1 mix of IF-Avr9-Nt with IF-Wt-Nt was injected into $C f 9$ tobacco and $C f 9$ tomato. We could not distinguish IF-Avr9-Nt mixed with IF-Wt-Nt from IF-Avr9-Nt mixed with IF-Wt-Bn. Both mixtures induced a necrotic response in $C f 9$ tobacco and $C f 9$ tomato at 1 to 2 days following injection (data not shown). Based on this, we did not find

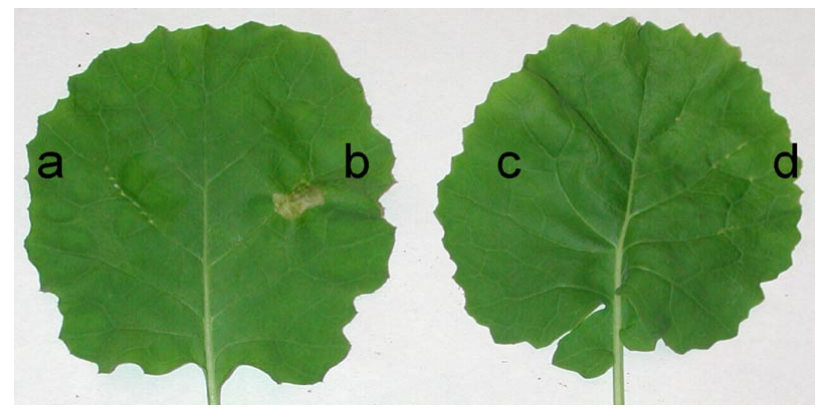

Fig. 1. Avr9-dependent necrosis in transgenic $C f 9$ oilseed rape leaves. Transgenic $C f 9$ oilseed rape leaves after injection with four different types of intercellular fluid (IF). Two IF contained the Avr9 elicitor: IFAvr9-Bn-1 $\left(0.2 \mathrm{mg}\right.$ of crude protein ml ${ }^{-1}$ of IF) and IF-Avr9-Bn-h ( $0.4 \mathrm{mg}$ of crude protein $\mathrm{ml}^{-1}$ of IF). The two IF lacking the Avr9 protein were extracted from wild-type oilseed rape: IF-Wt-Bn-1 (0.2 mg of crude protein $\mathrm{ml}^{-1}$ of IF) and IF-Wt-Bn-h $\left(0.4 \mathrm{mg}\right.$ of crude protein $\mathrm{ml}^{-1}$ of IF). b, A gray necrotic response was evident on a transgenic $C f 9$ oilseed rape leaf only after injection of IF-Avr9-Bn-h. No symptoms appeared after the injection of a, IF-Avr9-Bn-1, c, IF-Wt-Bn-1, or d, IFWt-Bn-h. Photograph was taken 5 days after injection. any indication of the presence of inhibitors of Avr9 activity in the intercellular fluid of oilseed rape.

When comparing $C f 9$ oilseed rape with $C f 9$ tobacco or $C f 9$ tomato, we observed that $C f 9$ oilseed rape always responded to Avr9 injection slightly slower than $C f 9$ tobacco or $C f 9$ tomato. In $C f 9$ oilseed rape and $C f 9$ tomato, necrosis developed solely within the injected section. After injection of IF-Avr9Nt-h, only $C f 9$ tobacco plants developed a necrosis, which was not confined to the IF injection area but spread over the rest of the leaf (Table 1). Based on these observations, it can be assumed that threshold levels also exist for Cf9 activity. In addition, the fact that the HR response was stronger in tobacco than in tomato indicates that the lowest threshold is not necessarily present in the original plant.

\section{Avr9-specific induction of local defense responses in oilseed rape plants expressing $\boldsymbol{C} \boldsymbol{f}$.}

In $C f 9$ tomato, the injection of Avr9 protein induces the synthesis of PR proteins such as chitinases and $\beta$-1,3-glucanases (Wubben et al. 1996). We studied whether an Avr9-induced HR in $C f 9$ oilseed rape was accompanied by a similar induction of endogenous defense genes. Northern analyses were performed on RNA leaf material obtained from $C f 9$ oilseed rape leaves (pCF1) injected with water, IF-Wt-Bn-h, IF-Avr9$\mathrm{Bn}-1$, or IF-Avr9-Bn-h in order to study the induction of the $P R 1, P R 2$, and $C x c 750$ defense genes following these treatments. For comparison, $P R$ gene expression was studied following benzothiadiazole (BTH) treatment. BTH is a chemical SA analog known to induce the expression of defense genes in several plants (Sticher et al. 1997).

We observed a similar accumulation of $P R 1, P R 2$, and Cxc750 mRNA $12 \mathrm{~h}$ after injection of IF-Avr9-Bn-h or after $1 \mathrm{mM}$ BTH treatment (Fig. 3D and E). At later time points (24 and $48 \mathrm{~h}$ ), a stronger accumulation of defense genes was detected in BTH-treated leaves, indicating that BTH is a more potent inducer of defense genes than the Avr9-mediated HR

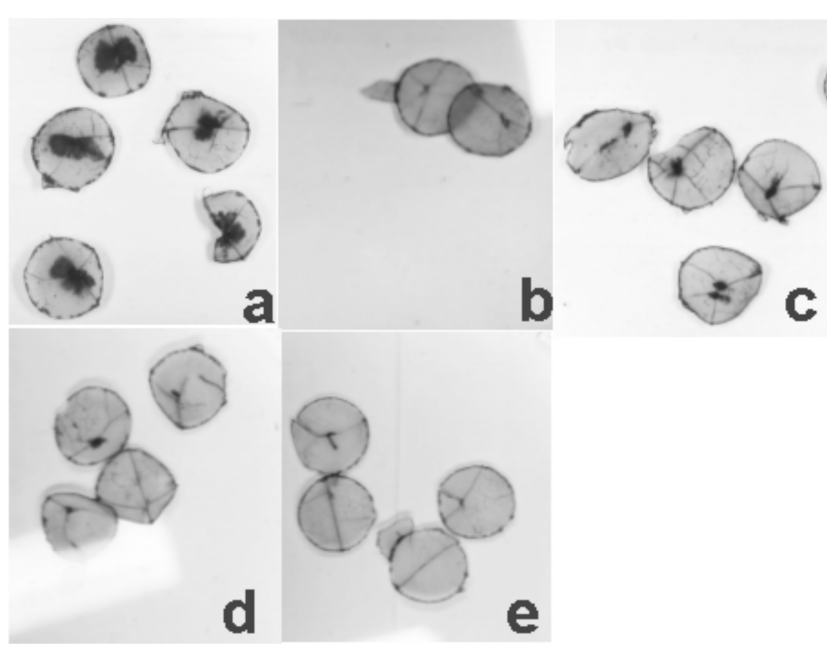

Fig. 2. Detection of Avr9-dependent cell death in $C f 9$ oilseed rape leaf discs. Cf9 oilseed rape leaves were injected with a, IF-Avr9-Bn-h (0.5 mg of crude protein $\mathrm{ml}^{-1}$ of intercellular fluid ([IF]), b. IF-Avr9-Bn$1\left(0.3 \mathrm{mg}\right.$ of crude protein $\mathrm{ml}^{-1}$ of IF), c. IF-Wt-Bn-h ( $0.5 \mathrm{mg}$ of crude protein ml ${ }^{-1}$ of IF), d, IF-Wt-Bn-l (0.3 mg of crude protein $\mathrm{ml}^{-1}$ of IF), or e, water. At $1 \mathrm{~h}$ after injection, leaf discs (diameter of $1 \mathrm{~cm}$ ) were cut and incubated in $0.25 \%$ Evans blue. 
reaction in the $C f 9$ plant. The injection of IF-Avr9-Bn-1 also induced considerable $P R 1$ and $P R 2$ expression $12 \mathrm{~h}$ post injection, but to a lower extent than the injection of IF-Avr9-Bn-h (Fig. 3C). The weaker signal observed in the IF-Avr9-Bn-h$24 \mathrm{~h}$ sample was probably the result of a lower amount of RNA blotted on the membrane (Fig. 3). We also observed the expression of $P R 1, P R 2$, and $C x c 750$ after control treatments (water injection or IF-Wt-Bn injection) (Fig. 3A and B). The signal strength, however, clearly showed a stronger and quicker induction of $P R$ expression upon IF-Avr9-Bn injection or BTH treatment.

Our results indicated the induction of endogenous defense responses following an Avr9-mediated HR in $C f 9$ oilseed rape. The differences in the induction pattern of $P R$ gene expression after injection of Avr9-containing IF or in control treatments (water injection and IF-Wt-Bn injection) were clearest at the earliest time point studied (12 h). Additionally, in the absence of cell death symptoms (IF-Avr9-Bn-1 injections), defense responses were induced, although to a lesser degree, qualitatively and quantitatively (Fig. 3).

\section{Presence of $C f^{9}$ and $A v r 9$ genes in $\mathrm{F}_{1}$ progeny of oilseed rape does not lead to seedling death.}

Reciprocal crosses between $C f 9$ and Avr 9 expressing tobacco or tomato plants result in seed or seedling lethality (Hammond-Kosack et al. 1996; Hammond-Kosack et al. 1998). To determine whether a similar phenotype occurs in oilseed rape, reciprocal crosses were made between transformants hemizygous for a single $C f 9$ T-DNA (pCF1) or Avr9 TDNA copy (pAVR1). Pollinated $C f 9$ or Avr9 plants developed normal pods and seeds. Segregation of each of the transgenes fitted the expectations for a single dominant gene. Using specific PCR primers, it was confirmed that $25 \%$ of the plants contained both transgenes. Compared to plants carrying only one or no transgene, $\mathrm{F}_{1}(C f 9, A v r 9)$ plants demonstrated no phenotypic or developmental abnormality throughout their entire life cycle. In addition, microscopic observation of discolored leaves did not show the presence of micro-HRs in the $\mathrm{F}_{1}$ progeny that inherited both transgenes. The absence of phenotypic symptoms in $F_{1}$ plants might be the result of the

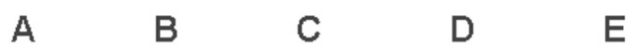

$\begin{array}{llllllllllllllllllll}0 & 12 & 24 & 48 & 0 & 12 & 24 & 48 & 0 & 12 & 24 & 48 & 0 & 12 & 24 & 48 & 0 & 12 & 24 & 48\end{array}$

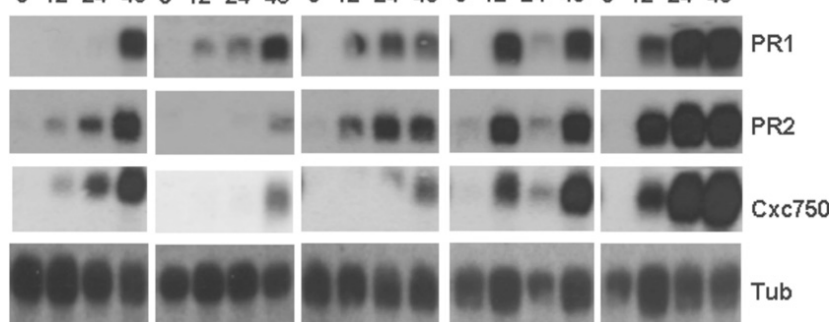

Fig. 3. $C f 9-A v r 9$ interaction induces endogenous defense responses in oilseed rape. Pathogenesis-related gene induction pattern in $C f 9$ oilseed rape leaves $0,12,24$, and $48 \mathrm{~h}$ after injection of $\mathbf{A}$, water, $\mathbf{B}$, IF-Wt-Bnh (0.4 mg of crude protein $\mathrm{ml}^{-1}$ of intercellular fluid [IF]), C, IF-Avr9Bn-1 (0.2 mg of crude protein $\mathrm{ml}^{-1}$ of IF), D, IF-Avr9-Bn-h $(0.4 \mathrm{mg}$ of crude protein $\mathrm{ml}^{-1}$ of IF), or $\mathbf{E}$, treatment with $1 \mathrm{mM}$ benzothiadiazole. RNA $(5 \mu \mathrm{g})$ was loaded on gel, and Northern blots were hybridized with a $P R 1, P R 2$, and Cxc750 probe. RNA quantity and quality on the blot was checked by hybridizing with a Tubulin probe. The experiment was repeated, and similar results were obtained. low expression levels of $C f 9$ and Avr9. Possibly, the Avr9 concentration in $F_{1}$ oilseed rape plants is similar to the Avr9 concentration present in low-concentrated IF-Avr9-Bn, which did not cause necrosis after injection in $C f 9$ oilseed rape plants. Consequently, this concentration might have been too low to cause seedling death. For that reason, two constructs were made to improve the expression levels of both transgenes in oilseed rape.

In the construct $\mathrm{pCF} 2$, the $C f 9$-cDNA sequence was placed behind a different version of the Cauliflower mosaic virus $35 \mathrm{~S}$ promoter, $\mathrm{p}_{35 \mathrm{~S}_{2}}$ (Odell et al. 1985), and the Cab22L untranslated leader sequence (Harpster et al. 1988) to optimize expression. In pAVR3, a similar promoter construct was used to control the expression of Avr9. The new set of transgenic oilseed rape plants was phenotypically identical to untransformed plants. Northern analyses revealed strong expression of $A v r 9$ in the transgenic plants. A $C f 9$ signal, however, was again detected only in RT-PCR and not in Northern analyses (data not shown). This result suggests that high expression of the $C f 9$ gene in oilseed rape could not be reached. Reciprocal crosses between plants carrying pCF2 and pAVR3 constructs also resulted in $\mathrm{F}_{1}$ plants carrying $C f 9$ and $A v r 9$ genes that, phenotypically, were not different from wild-type plants or plants carrying only $C f 9$ or $A v r 9$, thus confirming previous data.

\section{Enhanced resistance against Leptosphaeria maculans} in the $\mathrm{F}_{1}$ progeny of oilseed rape expressing $A v r \boldsymbol{9}$ and $C f \boldsymbol{~}$.

Plant resistance is not always associated with cell death symptoms (Bendahmane et al. 1999; Brading et al. 2000; Cole et al. 2001; De Jong et al. 2000; Govrin and Levine 2000; Hammond-Kosack et al. 1996; Lu and Higgins 1998; Yu et al. 1998). To study whether $\mathrm{F}_{1}$ plants carrying $C f 9$ and $A v r 9$ have elevated levels of resistance in the absence of cell death symptoms, we checked whether the $\mathrm{F}_{1}$ plants resulting from crosses between plants carrying pCF2 with plants carrying pAVR3 showed enhanced resistance levels to the hemibiotroph $L$. maculans (Desm.) Ces. \& De Not. We observed that disease development of L. maculans on $\mathrm{F}_{1}$ plants carrying only one of the transgenes was not significantly different from the disease development on wild-type plants at all observed time points (Fig. 4). At the onset of infection (7 and 10 days postinoculation [dpi]), disease development of $L$. maculans was delayed significantly on $\mathrm{F}_{1}(C f 9 X A v r 9)$ plants compared with disease development on wild-type plants or plants carrying only $C f 9$ or Avr9 (Fig. 4). From 14 dpi on, however, disease development of L. maculans was similar on all different genotypes (Fig. 4). Similar results were obtained on $F_{1}$ plants taken from crosses of plants carrying pCF1 with plants carrying pAVR1. Thus, our observations were independent of the promoters that were used to express $C f 9$ or Avr 9 genes. Both groups of $\mathrm{F}_{1}$ progeny exhibited a similar level of resistance.

\section{Induction of defense responses in $F_{1}$ progeny of oilseed rape expressing $A v r \boldsymbol{9}$ and $C \boldsymbol{f} 9$.}

Because enhanced resistance was observed in $\mathrm{F}_{1}$ plants after L. maculans infection, we checked whether this was correlated to higher levels of $P R$ gene expression. RNA from $F_{1}$ (pCF2XpAVR3) and wild-type leaves was extracted and PRI expression was studied with Northern analyses. We did not observe elevated levels of $P R 1$ gene expression in the leaf 
material of $F_{1}$ plants compared with wild-type plants (Fig. 5, 0 -h time points). In the absence of a pathogen challenge, $P R 1$ gene expression pattern seemed similar in $F_{1}$ and wild-type plants. This result cannot exclude the possibility, however, that enhanced resistance in $\mathrm{F}_{1}$ plants is the result of a quicker, stronger, or longer expression of $P R$ genes after pathogen infection.

To further investigate this possibility, the expression pattern of PRl in $\mathrm{F}_{1}$ and wild-type plants was checked at 6,12 , 24,48 , and $72 \mathrm{~h}$ postinoculation with $L$. maculans. A strong PRl transcript was observed $6 \mathrm{~h}$ postinoculation in $\mathrm{F}_{1}$ as well as in wild-type plants, indicating that both plant types react in a similar time frame to pathogen challenges via the induction of endogenous defense responses (Fig. 5). In wildtype plants, the strongest $P R I$ signal was observed $12 \mathrm{~h}$ postinoculation, and weaker $P R 1$ signals were detected 24, 48 , and $72 \mathrm{~h}$ postinoculation. In $\mathrm{F}_{1}$ plants, a strong $P R 1$ signal was still detected 24,48 , and $72 \mathrm{~h}$ after inoculation, indicating that elevated expression levels of $P R 1$ lasted for a longer time (Fig. 5). We conclude that at early time points after infection, the strength and rapidity of $P R I$ expression was comparable in wild-type and $F_{1}$ plants and neither quicker nor stronger in the $F_{1}$ plants. A prolonged strong expression of $P R l$ in $\mathrm{F}_{1}$ plants, however, might explain why disease development of $L$. maculans was more delayed than it was in the wild type plants.

\section{Injection of Avr9}

into $\boldsymbol{C} \boldsymbol{f} \boldsymbol{9}$ oilseed rape leaves delays blackleg disease.

The HR is believed to deprive pathogens from nutrients and food supply and is, consequently, considered to be one of the most important factors in impeding the growth of biotrophic pathogens (Gilchrist 1998). In order to test the direct effect of the HR against $L$. maculans, we injected leaves of $C f 9$ oilseed rape (pCF1) with IF-Avr9-Bn and inoculated the injection sites with $L$. maculans. We injected high- and lowconcentrated IF-Avr9-Bn into $C f 9$ oilseed rape to study the importance of cell death for the control of $L$. maculans. For comparison, L. maculans also was inoculated on IF-Wt-Bninjection sites.

Disease development of L. maculans $\left(10^{6}\right.$ spores per $\left.\mathrm{ml}\right)$ was similar on water and IF-Wt-Bn-injected leaf areas, indicating that there was no IF effect on pathogen development (data not shown). Disease symptoms caused by L. maculans, however, developed significantly slower on IF-Avr9-Bn-hinjected leaf areas than on water-injected leaf areas during the first 2 weeks after co-treatment (Fig. 6). Compared with water injection, the injection of IF-Avr9-Bn-l had no significant restricting effect on L. maculans. Nevertheless, a small delay in disease development of the pathogen was observed on the IF-Avr9-Bn-1-injected area (Fig. 6). At later time points (17 and 21 days after co-treatment), symptoms developed similarly on water, IF-Avr9-Bn-l, and IF-Avr9-Bn-h-injected leaf

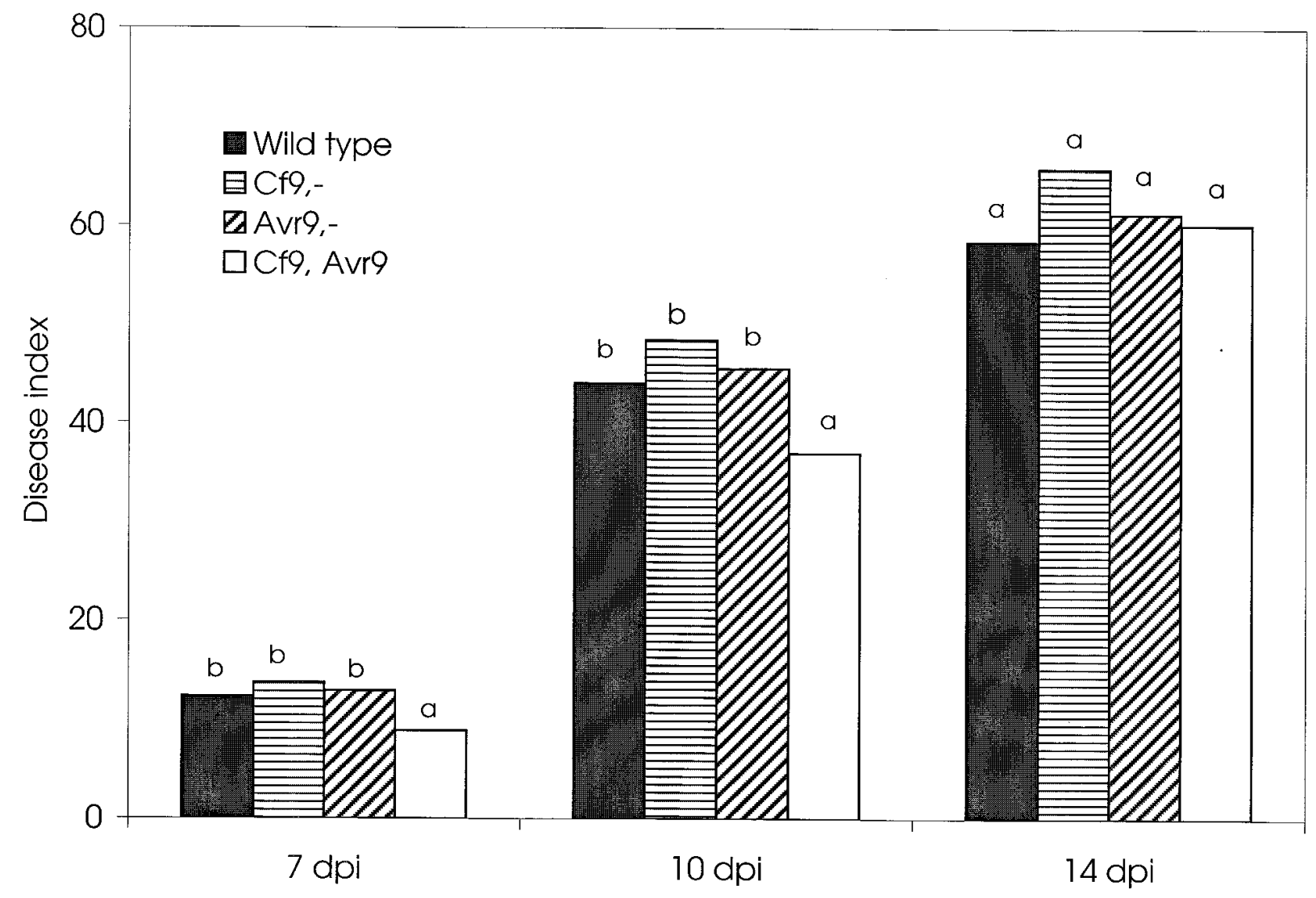

Fig. 4. Resistance level of $\mathrm{F}_{1}(C f 9$, Avr 9$)$ plants to Leptosphaeria maculans in the absence of cell death symptoms. Leaves of the $\mathrm{F}_{1}$ progeny segregating for $C f 9$ and $A v r 9$ were inoculated with $L$. maculans $\left(10^{6}\right.$ spores $\left.\mathrm{ml}^{-1}\right)$. Disease symptoms were scored 7, 10, 14, 17, and 21 days postinoculation (dpi; 17 and $21 \mathrm{dpi}$ are not shown), according to the diameter of the lesions. A disease index was calculated. Bars represented with the same letter per time point are not significantly different $(p=0.05$, Mann-Whitney test). 
areas (data not shown). In conclusion, our results indicate that induction of a HR by Avr9 injection on the inoculation site of L. maculans delayed disease development of this pathogen, but only at its initial infection stage. Induction of a HR without cell death symptoms had a smaller but non-significant effect on the development of the pathogen.

\section{DISCUSSION}

Functional expression of the tomato $C f 9$ gene and fungal $A v r 9$ gene in transgenic oilseed rape lines.

It is accepted that a $R$ gene and the corresponding pathogen $A v r$ gene are the basic components required for triggering a HR. Expression of corresponding $R-A v r$ gene pairs in more or less related plant species is considered to be a tool for engineering disease resistance. Several examples indicate that the functional transfer of $R$ genes from one plant family to another, however, might have its limitations. For instance, the $B s 2$ gene that originates from pepper, a member of the Solanaceae spp., functions only in Solanaceous spp. plants. This phenomenon also was shown for the RPS 2 gene of Arabidopsis thaliana. RPS2 was shown to be nonfunctional in transgenic tomatoes (Tai et al. 1999). It was demonstrated that the transient expression of the $C f 9-A v r 9$ gene pair in a number of plants belonging to the Solanaceae spp., including potato, different Nicotiana species, and Petunia hybrida, induced necrotic or chlorotic responses (Hammond-Kosack et al. 1998; Van der Hoorn et al. 2000). Transient co-expression of the Cf9-Avr9 gene pair in lettuce, Arabidopsis, radish, lupine, pea, or flax, however, did not induce necrotic responses (Van der Hoorn et al. 2000). In general, this phenomenon is referred to as restricted taxonomic functionality (RTF) (Tai et al. 1999) and suggests that components required for functional signal transduction pathways leading to the induction of defense responses are conserved only within plant families. So far, only one example shows the functional expression of a $C f-A v r$ gene pair in a distantly related plant species. It seems that lettuce, belonging to the Asteraceae family, contains the major components required for functional expression of the $C f 4$ Avr4 gene pair from tomato and C. fulvum (Van der Hoorn et al. 2000).
We demonstrated the functional introduction of the $C f 9$ and Avr 9 genes in oilseed rape. Although the foreign gene pair did not function identically to that observed in the tomato plant, there was more similarity than suggested by the RTF theory. We observed an Avr9-dependent HR in transgenic Cf9 oilseed rape. $C f 9$ oilseed rape responded to IF-Avr9-Bn injection by the induction of cell death. To date, the tomato- $C f 9$ gene was functionally introduced into tobacco and potato, two plant species sexually incompatible with tomato but belonging to the same plant family (Hammond-Kosack et al. 1998). There are indications that the interaction between $C f 9$ and $A v r 9$ occurs indirectly (Joosten and De Wit 1999), requiring additional components in order for the $C f 9-A v r 9$ interaction to result in a HR. The observation of a functional $C f 9-A v r 9$ interaction in oilseed rape supports the hypothesis that these components are highly conserved and are present in a distantly related plant family. When IF-Avr9-Bn containing a lower amount of total protein was injected into $C f 9$ oilseed rape, however, we could neither observe microscopic nor phenotypic cell death symptoms. It seems that a threshold is necessary for an irrevocable commitment to death. This observation also was made by De Jong et al. (2000) and Lu and Higgins (1998), who reported that the Avr9-containing IF diluted to a certain point did not induce necrosis in $C f 9$ tobacco cell suspensions and $C f 9$ tomato plants, respectively. The concentration effect also might explain why a difference in activity could be observed when comparing IF extracted from $A v r 9$ tobacco with IF originating from Avr9 oilseed rape. The difference in activity between the Avr9 proteins was probably not the result of the presence of Avr9-inhibiting components in the IF of oilseed rape. More likely, it resulted from a relatively higher amount of Avr9 protein present in IF-Avr9-Nt.

In $C f 9$ tomato and $C f 9$ tobacco, necrotic symptoms were still observed when IF-Avr9-Bn-1 was injected. These results indicate that the detection limit for Avr9 peptide in $C f 9$ tomato and $C f 9$ tobacco is lower than in transgenic $C f 9$ oilseed rape. Moreover, the dilution experiment in tomato and oilseed rape suggests that the threshold Avr9 amount necessary to observe cell death is much higher in $C f 9$ oilseed rape than in $C f 9$ tomato. The observation that different plant species expressing the $C f 9$ gene react differently after the injection of Avr9 elici-

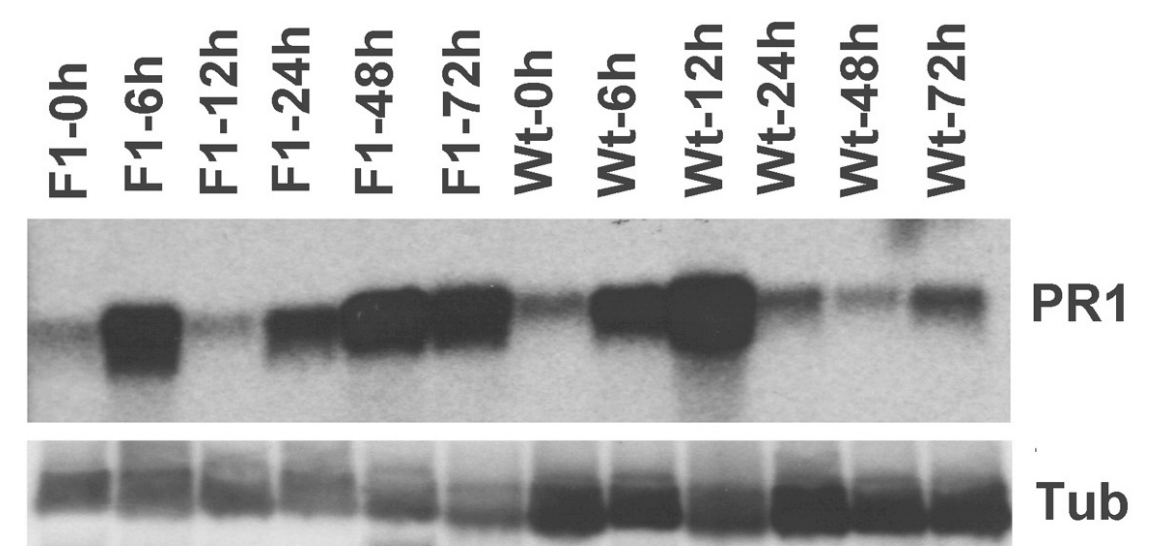

Fig. 5. $P R 1$ gene expression pattern in wild-type and $\mathrm{F}_{1}(C f 9, A v r 9)$ plants before and after Leptosphaeria maculans inoculation. Leaves of $\mathrm{F}_{1}$ and wildtype plants were inoculated with $L$. maculans $\left(10^{6}\right.$ spores $\left.\mathrm{ml}^{-1}\right)$. RNA samples were taken before and $6,12,24,48$, and $72 \mathrm{~h}$ after inoculation. RNA $(5 \mu \mathrm{g})$ was loaded, and Northern blots were hybridized with a $P R 1$ probe. RNA quantity and quality on the blot was checked by hybridizing with a Tubulin probe. The experiment was repeated, and similar results were obtained. 
tor also was made by Hammond-Kosack et al. (1998), who showed that $C f 9$ tobacco has a stronger and quicker responsiveness to Avr9 than $C f 9$ tomato or $C f 9$ potato.

We detected that the presence of $C f 9$ and Avr 9 gene products in oilseed rape resulted in the local induction of defenserelated genes. In $C f 9$ tomato, injection of the Avr9 protein induces the synthesis of chitinases and $\beta$-1,3-glucanases (Wubben et al. 1996). Similarly, the presence of the $C f 9$ and Avr9 genes in oilseed rape induces expression of plant defense-related genes such as $P R 1, C x c 750$, and $P R 2$. Interestingly, we also observed the local induction of $P R$ gene expression when injecting IF with Avr9 concentrations that did not cause cell death symptoms. Especially at earlier time points, the differences between IF containing Avr9 and IF-Wt-Bn or water were very clear. For resistance responses, this difference in rapidity of induction of defense genes has been shown to be important. The observed induction of defense responses after injection of Avr9-containing IF was weaker than it was after BTH treatment, but still considerable.

In contrast to results obtained in Solanaceae spp., reciprocal crosses of $C f 9 \times A v r 9$ oilseed rape did not result in the seedling death of the B. napus $\mathrm{F}_{1}$ progeny. In tomato and tobacco, developmentally regulated cell death is observed on expression of the fungal avirulence gene Avr9 in seedlings carrying the disease resistance gene $C f 9$ (Hammond-Kosack et al. 1994; Hammond-Kosack et al. 1998; Honée et al. 1995; Honée et al. 1998). The absence of a phenotype after crossing Cf9 with Avr9 plants is rather surprising because a necrotic response could be obtained when injecting IF containing concentrated amounts of Avr9 in $C f 9$ plants. We assume that there are different factors to explain this discrepancy. Exact quantification of the Avr9 protein in the IF was not possible when the IF extraction protocol was used. Consequently, it was difficult to conclude on the exact concentration of Avr9 in injection experiments in $C f 9$ oilseed rape plants. There also is strong evidence that the level of $C f 9$ gene expression was not sufficiently high to cause seedling death. The detection of $C f 9$ gene expression, even when under control of the strong constitutive $\mathrm{p}_{35 \mathrm{~S}_{2}}$ promoter, only was successful with RT-PCR. Possibly, the high expression of the $C f 9$ gene in oilseed rape is lethal, and only transformants showing lower expression levels are recovered. In addition, we observed that the $C f 9$ gene was less sensitive in oilseed rape than in tomato or tobacco. In addition to demonstrating that $C f 9$ tomato and $C f 9$ tobacco always responded faster to Avr9 injection than does oilseed rape, we showed that the Avr9 detection limit in $C f 9$ tomato was much lower than in $C f 9$ oilseed rape.

In general, we conclude that the $C f 9-A v r 9$ system seems to work less efficiently in oilseed rape than in tomato. Nevertheless, the $C f 9-A v r 9$ interaction was shown to induce a HR and endogenous signaling pathways in oilseed rape, which indicates that the functional expression of a resistance gene is not restricted to closely related plant species but also possible in more distantly related plant species. We assume that the absence of the cell death phenotype in $\mathrm{F}_{1}(C f 9, A v r 9)$ progeny was not the result of the absence of particular signal transduction components, leading to resistance. $F_{1}$ plants showed a similar $P R 1$ induction pattern to wild-type plants after the $L$. maculans challenge. The rapidity of $P R$ gene expression was comparable to previously reported data on $P R$ gene expression in B. napus after L. maculans infection (Dixelius 1994; Fristensky et al. 1999; Lamkadmi et al. 1996; Rasmussen et al. 1992). Moreover, the observation that expression of PRI was induced in $\mathrm{F}_{1}(C f 9, A v r 9)$ plants for a longer period than in

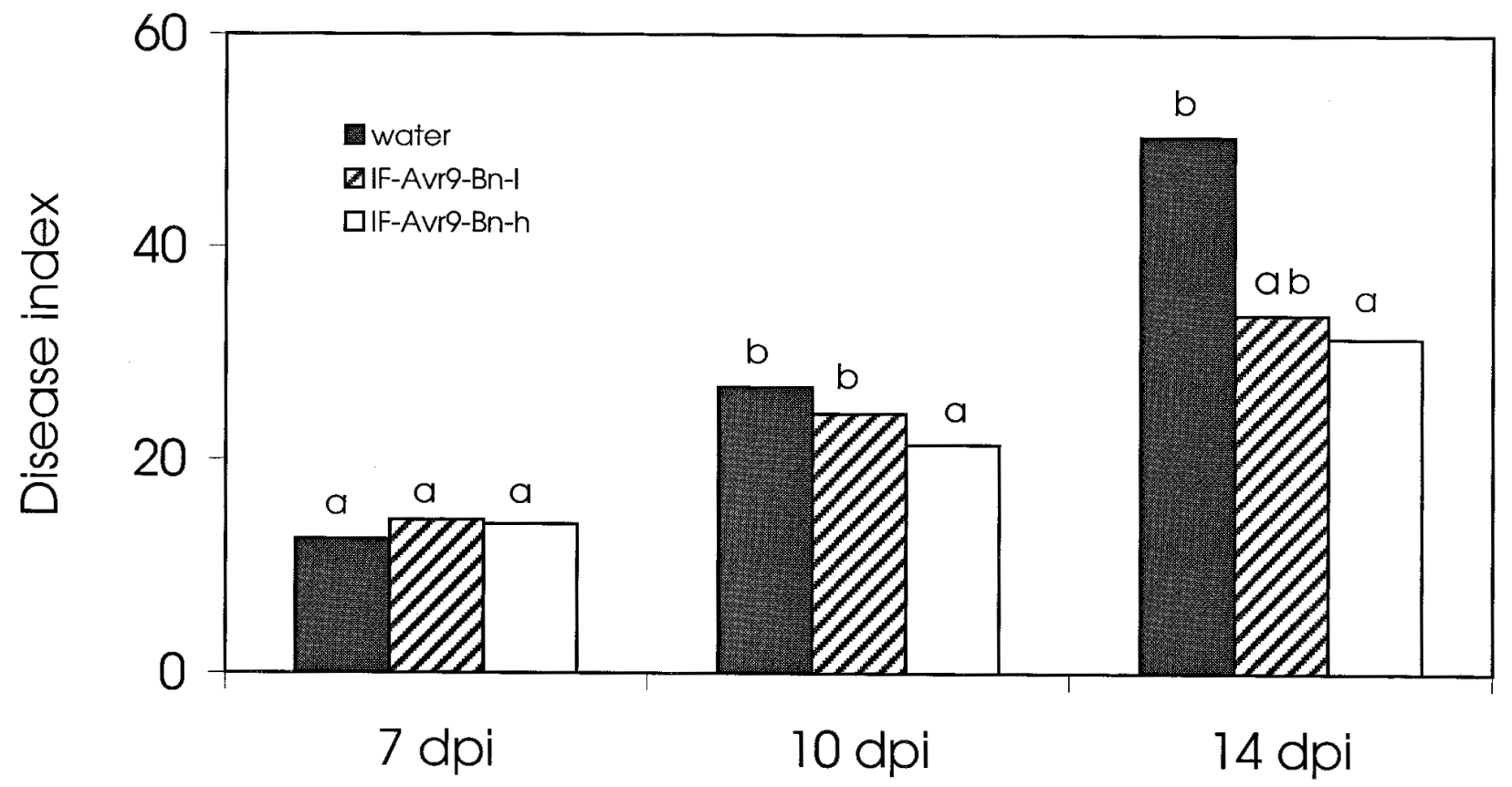

Fig. 6. Local effect of the Avr9-mediated hypersensitive response on Leptosphaeria maculans in $C f 9$ oilseed rape. Cf9 oilseed rape leaves were injected with water, IF-Avr9-Bn-1 (0.2 mg of crude protein ml ${ }^{-1}$ of intercellular fluid [IF]) or IF-Avr9-Bn-h (0.4 mg of crude protein ml ${ }^{-1}$ of IF) and subsequently inoculated with $L$. maculans $\left(10^{6}\right.$ spores per $\left.\mathrm{ml}\right)$. Lesions caused by $L$. maculans were measured at $7,10,14,17$, and 21 days postinoculation (dpi). Disease indices are represented (17 and 21 dpi not shown). Bars represented with the same letter per time point are not significantly different ( $p=0.05$, MannWhitney test). 
wild-type plants suggests that signal transduction components leading to disease resistance are even more effectively induced. We believe that the main reason for the absence of a cell death phenotype in the $F_{1}$ progeny is the impossibility to reach certain threshold levels of Cf9, Avr9, or even third components required for their interaction.

\section{Avr9-induced response in $C f 9$ oilseed rape has a restricting effect on $L$. maculans in oilseed rape.}

The HR is considered to be one of the most important factors in impeding the growth of biotrophic pathogens (Gilchrist 1998). Consequently, it is believed that the induction of a HR at the infection point could stop the progress of pathogens in plants. In co-inoculation experiments, we observed that the development of $L$. maculans was retarded in the Avr9 injection zone of $C f 9$ oilseed rape leaves. The suppressing effect of cell death on the infection process of L. maculans, however, was observed only in its initial infection stage, and complete resistance was never observed. Delay of the infection process lasted approximately 2 weeks after inoculation, which might coincide with the switch from a biotrophic to a necrotrophic life style of L. maculans (Hammond et al. 1985). The observed resistance effect on $L$. maculans at the beginning of its infection process might be the result of the local activation of defense responses. Still, it is possible that the induction of defense responses after the $C f 9-A v r 9$ co-presence has no direct effect on the pathogen but is part of a broader general defense mechanism of the plant. In this case, the exact components involved in the enhanced resistance against $L$. maculans remain to be identified.

\section{Necessity of cell death in the establishment of disease resistance.}

The exact role of cell death in disease resistance is not yet completely understood. Some obligate biotrophic pathogens form intimate haustorial associations with living host cells, and plant cell death would deprive the pathogen from nutrients. In plant-pathogen relations involving necrotrophic interactions, however, the possible benefits of the induction of a $\mathrm{HR}$ are still unclear because these pathogens obtain their nutrients from dead plant cells. The observation that, in tomato, the induction of a HR has a restricting effect on the development of the biotrophs Oidium lycopersicum and C. fulvum and of the hemibiotroph Phytophthora infestans (Stuiver et al. 1998) indicates that the induced HR strategy might offer opportunities to control biotrophic pathogens. However, Govrin and Levine (2000) showed that the HR in A. thaliana facilitates infections of the necrotrophs Botrytis cinerea and Sclerotinia sclerotiorum. Both pathogens utilize the plant HR for rapid colonization of their hosts. Consequently, in order not to enhance disease caused by necrotrophic pathogens when engineering an inducible HR system in plants, it is necessary that the expression of the Avr 9 or $C f 9$ gene is controlled by a promoter that is induced only by biotrophic pathogens and not by necrotrophic pathogens. Another possibility is to concentrate on the effect of resistance, without the induction of cell death.

It was shown that the activation of defense responses and induction of enhanced resistance could be observed without the occurrence of phenotypic cell death symptoms. Yu et al. (1998; 2000) identified A. thaliana dndl mutants. Despite the absence of a normal HR, these mutants still showed a highly effective $R$ gene-mediated restriction of avirulent Pseudomonas syringae strains. The mutants constitutively demonstrated defense mechanisms such as the synthesis of PR proteins and the production of high levels of SA. The $d n d l$ mutants showed enhanced resistance against virulent viruses, bacteria, and fungi (Govrin and Levine 2000; Yu et al. 1998; Yu et al. 2000), suggesting that HR cell death, per se, is not always required for the successful restriction of pathogen growth. Recently, the DNDl gene was shown to encode an ion channel (Clough et al. 2000), adding evidence to previous physiological and biochemical work that associates ion fluxes with the induction of plant defenses (Scheel 1998). Lu and Higgins (1998) demonstrated that a considerable oxidative burst occurs in $C f 9$ tomato when injected with Avr9 elicitor dilutions that do not cause necrosis. De Jong et al. (2000) obtained similar results in $C f 9$ tobacco cell suspensions when injecting Avr9 protein concentrations that were lower than minimal concentrations required to induce necrosis. Additionally, Costet et al. (1999) showed that the infiltration of a diluted amount of fungal HR-inducing glycoprotein in tobacco leaves induced enhanced virus resistance and defense responses, without cell death or oxidative burst. Further indications suggesting the separation of cell death and disease resistance are the effects of humidity and temperature, which can inhibit the HR response without compromising resistance (Hammond-Kosack et al. 1996). In addition, Brading et al. (2000) observed that resistance against a $C$. fulvum race expressing the Avr9 gene was retained in NahG $C f 9$ tomato, although no necrosis could be induced in NahG Cf9 plants after the infiltration of IF carrying the Avr9 protein.

To this list of examples, which uncouple cell death from resistance, we were able to add several observations. We showed the activation of defense without the occurrence of phenotypic cell death symptoms and demonstrated that $F_{1}$ plants carrying $C f 9$ and Avr9 genes in the absence of cell death had a higher resistance level during the initial stages of L. maculans infection compared with wild-type plants or plants carrying only $C f 9$ or $A v r 9$. In addition, we demonstrated that some reduction in the spread of L. maculans could be seen without the occurrence of cell death and that the reduction was stronger when cell death was induced on the infection site of the pathogen.

The enhanced L. maculans resistance levels observed in $\mathrm{F}_{1}$ plants and in co-treatment experiments might be correlated to the expression of $P R$ genes. The studied $P R$ genes were used as indicators of $P R$ gene induction. Their expression suggests that other defense genes also should be induced. In $\mathrm{F}_{1}$ plants, the expression of PRI was induced in a similar manner as in wild-type plants, yet for a longer duration. The longer availability of high amounts of PR proteins such as PR1 in $F_{1}$ plants might explain why disease development of $L$. maculans was more delayed in these plants. Also, the injection of Avr9 in $C f 9$ oilseed rape induced expression of $P R$ genes. Thus, it is likely that the enhanced resistance levels that we observed in the absence of cell death were correlated with the induction of endogenous defense responses. It remains to be proven, however, that the studied $P R$ genes play a role in disease resistance to L. maculans. Moreover, it is necessary to investigate whether, in the absence of cell death, the induction of these endogenous defense responses is sufficiently strong to lead to a significant reduction in the spread of L. maculans. 
We conclude that it might be possible to engineer disease resistance without the necessity to induce cell death, opening perspectives for the control of biotrophic as well as necrotrophic pathogens. Nevertheless, it still has to be demonstrated whether an inducible system without cell death results in a sufficient level of resistance.

\section{MATERIALS AND METHODS}

\section{Plant material.}

An isogenic line of tomato (Lycopersicon esculentum) cv. Moneymaker, which is homozygous for the $C f 9$ gene, was supplied by P. De Wit, Wageningen University, The Netherlands. Transgenic tobacco (Nicotiana tabacum cv. Petit Havana), homozygous for the $C f 9$ or $A v r 9$ gene, and constructs containing the respective genes, were supplied by J. Jones, John Innes Centre, Norwich, U.K. We used five constructs for oilseed rape transformation: pAVR1 (LB-p35S $\mathrm{S}_{1}$-Avr9-3'TPIII-pSsuAra-bar-RB), pAVR2 (LB-p35S ${ }_{1}$-Avr9R8K-3'TPI-IIpSsuAra-bar-RB), pCF1 (LB-pCf9-Cf9-3'nos-pSsuAra-barRB), pAVR3 (LB-p35S 2 -cab22L-Avr9-3'TPI-II-pSsuAra-bar-

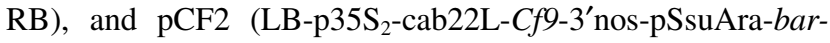
$\mathrm{RB})$.

By including the sequence of the PR1a signal peptide from tobacco in the constructs pAVR1, pAVR2, and pAVR3, the Avr9 or Avr9R8K elicitor was targeted extracellularly. Transformation was performed according to De Block et al. (1989). The regenerated transgenic oilseed rape plants were phenotypically identical to untransformed plants. Transformants carrying up to two T-DNA integrations were selected by Southern analyses, according to Sambrook et al. (1989). Oilseed rape plants were soil grown in a growth chamber at $20^{\circ} \mathrm{C}$ in the light and $18^{\circ} \mathrm{C}$ in the dark. A light intensity of $35 \mu \mathrm{mol}$ $\mathrm{m}^{-2}$ per $\mathrm{s}$ was supplied for $16 \mathrm{~h}$. The relative humidity in the greenhouse was 70 to $80 \%$.

\section{Gene expression analyses.}

Total RNA was extracted from 5-week-old, hemizygous transgenic oilseed rape $\left(\mathrm{T}_{0}\right.$ and $\mathrm{T}_{1}$ generation). RNA was prepared according to the TriZol method (Life Technologies, Rockville, MD, U.S.A.). Samples of $5 \mu \mathrm{g}$ of RNA were loaded on gel for Northern hybridization (Sambrook et al. 1989). Blots were hybridized with $C f 9$ or $A v r 9$ RNA probes. For use in RT-PCR analyses, RNA was treated with DNase I (Life Technologies) and quantified spectrophotometrically. RNA $(5 \mu \mathrm{g})$ was used in a first-strand reaction with SuperScript RNase H reverse transcriptase (Life Technologies). Synthesis of cDNA was detected by PCR with $C f 9$ (5'-AGC TCA CGG TTA GGT TTC C-3' and 5'-CAC GCA TTG TGG GAT TGT TCC-3') and Avr9 (5'-GTA CAC ATT GGA GCT TAT GAA A-3' and 5'-ATG GGA TTT GTT CTC TTT TCA C-3') primer pairs and Taq DNA Polymerase I (Boehringer Mannheim, Mannheim, Germany). Hemizygous lines that showed the most intense amplification of the respective $C f 9$, $A v r 9$, or $A v r 9 R 8 K$ fragments in RT-PCR were used in additional experiments.

\section{Isolation of the Avr9 elicitor, and assay of the biological activity.}

IF containing Avr9 was recovered from Avr9 expressing oilseed rape plants (IF-Avr9-Bn), according to De Wit and
Spikman (1982). For comparison, IF lacking Avr9 elicitor was recovered from wild-type oilseed rape plants (IF-Wt-Bn). Protein amounts in the IF were determined by the method of Bradford (1976). The interveinal regions of fully expanded leaves were injected with 10 to $20 \mu \mathrm{l}$ of IF by a micro-syringe. Injected plants were incubated at $20^{\circ} \mathrm{C}$, with $80 \%$ relative humidity.

\section{Evans blue cell death staining.}

The fourth leaves of 5-week-old hemizygous $C f 9$ oilseed rape plants were injected with IF-Avr9-Bn-l, IF-Avr9-Bn-h, IF-Wt-Bn-l, IF-Wt-Bn-h, or water. At 15, 30, 60, and $120 \mathrm{~min}$ after injection, leaf discs of $1.5 \mathrm{~cm}$ in diameter, including the injection zone, were cut off and incubated in $1 \mathrm{ml}$ of $0.25 \%$ Evans blue (Sigma, St. Louis, MO, U.S.A.) solution for $5 \mathrm{~min}$. Leaf discs were subsequently cleared in $70 \%$ ethanol and analyzed macroscopically and microscopically.

\section{Detection of PR gene expression.}

The fourth leaves of 5-week-old hemizygous $C f 9$ oilseed rape leaves were injected with water, IF-Avr9-Bn-1 (0.2 mg of crude protein per $\mathrm{ml}$ of IF), IF-Avr9-Bn-h (0.4 mg of crude protein per $\mathrm{ml}$ of IF) so that the leaves were covered completely by the injection areas (i.e., the injection sites together with $1 \mathrm{~cm}$ of peripheral leaf tissue). For comparison, leaves were injected with IF-Wt-Bn $(0.4 \mathrm{mg}$ of crude protein per $\mathrm{ml}$ of IF) or sprayed until run off with $1 \mathrm{mM}$ chemical SAR inducer BTH. Total leaves were harvested before and 12, 24, and $48 \mathrm{~h}$ after treatments, and RNA was prepared according to the TriZol method. We used $5 \mu \mathrm{g}$ of RNA in a Northern hybridization. Blots were hybridized with a $P R 1, P R 2$, or Cxc750 probe (Fristensky et al. 1999).

\section{Fungal material and inoculation method.}

L. maculans isolate $\mathrm{M}_{1}$ was grown on V8 agar supplemented with Rose Bengal for 3 weeks. A pycnidiospore suspension was made by flooding the plates with sterile water and scrubbing the spores from the plates. Spore concentration was determined with a haemocytometer and adjusted to $10^{6}$ spores per $\mathrm{ml}$.

The fourth leaf of 5-week-old $\mathrm{F}_{1}(C f 9, A v r 9)$ plants was inoculated by applying $10 \mu \mathrm{l}$ of the $L$. maculans pycnidiospore suspension on wounded leaf sites. Inoculated wounds were covered with a small $\left(0.5 \mathrm{~cm}^{2}\right)$ filter paper, and leaves were wrapped in cling film for 3 days. Five inoculations were performed per leaf. In co-treatment experiments, the fourth leaf of 5-week-old oilseed rape plants was injected with water, IFAvr9-Bn-1 (0.2 mg of crude protein per ml), or IF-Avr9-Bn-h ( $0.4 \mathrm{mg}$ of crude protein per $\mathrm{ml}$ of IF; two injections per leaf). Inoculations were performed, as described, by applying $10 \mu \mathrm{l}$ of the pycnidiospore suspension $\left(10^{6}\right.$ spores per $\left.\mathrm{ml}\right)$ on the water- or IF-injected leaf sites. Disease was recorded by measuring the lesion size caused by L. maculans at 7, 10, 14, 17, and 21 dpi. Symptoms were classified on a scale of 0 to 7 $(0=$ no symptoms, $1=$ lesion size of 0 to $1.5 \mathrm{~mm}, 2=1.6$ to 3 $\mathrm{mm}, 3=4$ to $5 \mathrm{~mm}, 4=6$ to $10 \mathrm{~mm}, 5=11$ to $15 \mathrm{~mm}, 6=16$ to $20 \mathrm{~mm}, 7=21$ to $30 \mathrm{~mm}$ ). The disease index, a parameter indicating disease severity, was calculated as DI $=\{(n 0 \times 0)+$ $(n 1 \times 1)+\ldots+(n 7 \times 7)\} / N \times 7\} \times 100$ with $n 0$ to $n 7=$ the number of plants belonging to class 0 to 7 , and $N=$ the total number of plants. 


\section{Induction of defense responses}

\section{in $\mathrm{F}_{1}$ progeny expressing $A v r \boldsymbol{9}$ and $\boldsymbol{C} \boldsymbol{f} \boldsymbol{9}$.}

To assay expression of defense genes in $\mathrm{F}_{1}$ progeny expressing $A v r 9$ and $C f 9$ genes before and after pathogen challenge, the fourth leaf of 5-week-old plants was inoculated with $L$. maculans $\left(10^{6}\right.$ spores per $\left.\mathrm{ml}\right)$, as described above. For comparison, wild-type plants were inoculated in a similar way. Total leaves were harvested before and $6,12,24,48$, and $72 \mathrm{~h}$ after inoculation, and RNA was prepared according to the TriZol method. We used $5 \mu \mathrm{g}$ of RNA in a Northern hybridization. Blots were hybridized with a $P R 1$ probe (Fristensky et al. 1999).

\section{Experimental set up and statistical analyses.}

All inoculation experiments with $L$. maculans were performed at least twice, independently from each other. In each experiment, at least 50 inoculations per treatment were performed. Results of the most representative experiments are shown because conclusions from several independent experiments were similar. Data from inoculation experiments were analyzed statistically with the Mann-Whitney U-test (SPSS, Chicago, IL, U.S.A.). The $P=0.05$ threshold was used throughout all of the statistical procedures.

\section{ACKNOWLEDGMENTS}

We thank J. Botterman, Aventis CropScience Gent, Belgium, and J. Ellis, CSIRO, Canberra, Australia, for critical reading of the manuscript, and C. De Cock for technical assistance. We also thank C. Thomas and K. Hammond-Kosack, Sainsbury Laboratory, Norwich, U.K., for kindly providing constructs and seeds of transgenic tobacco, and J. Logemann, Mogen, Leiden, for providing Avr9R8K. Special thanks to B. Howlett, University of Melbourne, Australia, for providing the L. maculans strain, and B. Fristensky, University of Manitoba, Canada, for providing the PR1 Brassica probe. This work was supported by a specialization fellowship of the Flemish Institute for the Stimulation of ScientificTechnological Research in Industry (IWT, Brussels, Belgium).

\section{LITERATURE CITED}

Bendahmane, A., Kanyuka, K., and Baulcombe, D. C. 1999. The $R x$ gene from potato controls separate virus resistance and cell death responses. Plant Cell 11:781-791.

Bradford, M. 1976. A rapid and sensitive method for the quantitation of microgram quantities of proteins utilizing the principle of protein dye binding. Anal. Biochem. 72:248-254.

Brading, P. A., Hammond-Kosack, K. E., Parr, A., and Jones, J. D. G. 2000. Salicylic acid is not required for $C f 2$ - and $C f 9$-dependent resistance of tomato to Cladosporium fulvum. Plant J. 23:305-318.

Clough, S. J., Fengler, K. A., Yu, I.-C., Lippok, B, Smith, R. K., Jr., and Bent, A. F. 2000. The Arabidopsis dndl "defense, no death" gene encodes a mutated cyclic nucleotide-gated ion channel. Proc. Natl. Acad. Sci. USA 97:9323-9328.

Cole, A. B., Király, L., Ross, K., and Schoelz, J. E. 2001. Uncoupling resistance from cell death in the hypersensitive response of Nicotiana species to Cauliflower mosaic virus infection. Mol. Plant-Microbe Interact. 14:31-41.

Costet, L., Cordelier, S., Dorey, S., Baillieul F., Fritig, B., and Kauffmann S. 1999. Relationship between localized acquired resistance (LAR) and the hypersensitive response (HR): HR is necessary for LAR to occur and salicylic acid is not sufficient to trigger LAR. Mol. Plant-Microbe Interact. 12:655-662.

De Block, M., De Brouwer, D., and Tenning, P. 1989. Transformation of Brassica napus and Brassica oleracea using Agrobacterium tumefaciens and the expression of the bar and neo genes in transgenic plants. Plant Physiol. 91:694-701.

De Jong, C. F., Honée, G., Matthieu, H. A. J. J., and De Wit, P. J. G. M.
2000. Early defense responses induced by AVR9 and mutant analogues in tobacco cell suspensions expressing the $C f 9$-resistance gene. Physiol. Plant Pathol. 56:169-177.

De Wit, P. J. G. M. 1992. Molecular mechanisms of gene-for-gene systems in plant-fungus interactions and the application of avirulence genes in control of plant pathogens. Annu. Rev. Phytopathol. 30:391-418.

De Wit, P. J. G. M., and Spikman, G. 1982. Evidence for the occurrence of race and cultivar-specific elicitors of necrosis in intercellular fluids of compatible interactions of Cladosporium fulvum and tomato. Physiol. Plant Pathol. 21:1-11.

Dixelius, C. 1994. Presence of the pathogenesis-related proteins 2, Q and S in stressed Brassica napus and B. nigra plantlets. Phys. Mol. Plant Pathol. 44:1-8.

Flor, H. H. 1971. Current status of the gene for gene concept. Annu. Rev. Phytopathol. 9:275-296.

Fristensky, B., Balcerzak, M., Daifen, H., and Zhang, P. 1999. Expressed sequence tags from the defense response of Brassica napus L. to Leptosphaeria maculans. Mol. Plant Pathol. On-line http://www.bspp. org.uk/mppol/1999/0301fristensky.

Gilchrist, D. G. 1998. Programmed cell death in plant disease: The purpose and promise of cellular suicide. Annu. Rev. Phytopathol. 36:5990.

Govrin, E. M., and Levine, A. 2000. The hypersensitive response facilitates plant infection by the necrotrophic pathogen Botrytis cinerea. Curr. Biol. 10:751-757.

Greenberg, J. T. 1997. Programmed cell death in plant-pathogen interactions. Annu. Rev. Plant Physiol. Plant Mol. Biol. 48:525-545.

Hammond, K. E., Lewis, B. G., and Musa, T. M. 1985. A systemic pathway in the infection of oilseed rape plants by Leptosphaeria maculans. Plant Pathol. 34:557-565.

Hammond-Kosack, K. E., and Jones, J. D. G. 1996. Resistance genedependent plant defense responses. Plant Cell 8:1773-1791.

Hammond-Kosack, K. E., Harrison, K., and Jones, J. D. G. 1994. Developmentally regulated cell death on expression of the fungal avirulence gene $A v r 9$ in tomato seedlings carrying the disease-resistance gene Cf9. Proc. Natl. Acad. Sci. USA 91:10445-10449.

Hammond-Kosack, K. E., Silverman, P., Raskin, I., and Jones, J. D. G. 1996. Race-specific elicitors of Cladosporium fulvum induce changes in cell morphology and the synthesis of ethylene and SA in tomato cells carrying the corresponding $C f$ resistance gene. Plant Physiol. 110:1381-1394.

Hammond-Kosack, K. E., Tang, S., Harrison, K., and Jones, J. D. G. 1998. The tomato $C f 9$ disease resistance gene functions in tobacco and potato to confer responsiveness to the fungal avirulence gene product Avr9. Plant Cell 10:1-17.

Harpster, M. H., Townsend, J. A., Jones, J. D. C., Bedbrook, J., and Dunsmuir, P. 1988. Relative strengths of the $35 \mathrm{~S}$ cauliflower mosaic virus, $1^{\prime}, 2^{\prime}$ and nopaline synthase promoters in transformed tobacco, sugarbeet and oilseed rape callus tissue. Mol. Gen. Genet. 212:182190.

Honée, G., Melchers, L. S., Vleeshouwers, V. G. A. A., Van Roekel, J. S. C., and De Wit, P. J. G. M. 1995. Production of the AVR9 elicitor from the fungal pathogen Cladosporium fulvum in transgenic tobacco and tomato plants. Plant Mol. Biol. 29:909-920.

Honée, G., Buitink, J., Jabs, T., De Kloe, J., Sijbolts, F., Apotheker, M., Weide, R., Sijen, T., Stuiver, M., and De Wit, P. J. G. M. 1998. Induction of defense-related response in $C f 9$ tomato cells by the Avr9 elicitor peptide of Cladosporium fulvum is developmentally regulated. Plant Physiol. 117:809-820.

Hutcheson, S. W. 1998. Current concepts of active defense in plants. Annu. Rev. Phytopathol. 36:59-90.

Jones, D. A., Thomas, C. M., Hammond-Kosack, K. E., Balint-Kurti, P. J., and Jones, J. D. G. 1994. Isolation of the tomato $C f-9$ gene for resistance to Cladosporium fulvum by transposon tagging. Science 266:789-793.

Joosten, M. H. A. J., and De Wit, P. J. G. M. 1999. The tomatoCladosporium fulvum interaction: A versatile experimental system to study plant-pathogen interactions. Annu. Rev. Phytopathol. 37:335367.

Keller, H., Pamboukdjian, N., Ponchet, M., Poupet, A., Delon, R., Verrier, J.-L., Roby, D., and Ricci, P. 1999. Pathogen-induced elicitin production in transgenic tobacco generates a hypersensitive response and non-specific disease resistance. Plant Cell 11:223-235.

Kooman-Gersmann, M., Vogelsang, R., Hoogendijk, E. C. M., and De 
Wit, P. J. G. M. 1997. Assignment of amino acid residues of the AVR9 peptide of Cladosporium fulvum that determine elicitor activity. Mol. Plant-Microbe Interact. 10:821-829.

Lamkadmi, Z., Esnault, M.-A., and Le Normand, M. 1996. Characterization of a $23 \mathrm{kDa}$ polypeptide induced by Phoma lingam in Brassica napus leaves. Plant Physiol. Biochem. 34:589-598.

Lu, H., and Higgins, V. J. 1998. Measurement of active oxygen species generated in planta in response to elicitor Avr9 of Cladosporium fulvum. Physiol. Mol. Plant Pathol. 1:35-51.

May, M., Hammond-Kosack, K. E., and Jones, J. D. G. 1996. Involvement of reactive oxygen species, glutathione metabolism, and lipid peroxidation in the $C f$-gene-dependent defense responses of tomato cotyledons induced by race-specific elicitors of Cladosporium fulvum. Plant Physiol. 110:1367-1379.

Odell, J. T., Nagy, F., and Chua, N. H., 1985. Identification of DNA sequences required for activity of the cauliflower mosaic virus $35 \mathrm{~S}$ promotor. Nature 313:810-812.

Rasmussen, U., Giese, H., and Mikkelsen, J. D. 1992. Induction and purification of chitinase in Brassica napus L. spp. oleifera infected with Phoma lingam. Planta 187:328-334.

Sambrook, J., Fritsch, E. F., and Maniatis, T. 1989. Molecular Cloning: A Laboratory Manual, 2nd ed. Cold Spring Harbor Laboratory, Cold Spring Harbor, NY, U.S.A.

Scheel, D. 1998. Resistance response physiology and signal transduction. Curr. Opin. Plant Biol. 1:302-310.

Sticher, L., Mauch-Mani, B., and Metraux, J. P. 1997. Systemic acquired resistance. Annu. Rev. Phytopathol. 35:235-270.

Strittmatter, G., Janssens, J., Opsomer, C., and Botterman, J. 1995. Inhibition of fungal disease development in plants by engineering controlled cell death. Bio/Technology 13:1085-1089.

Stuiver, M., Honée, G., Weide, R., Tiglaar, H., Melchers, L., and De Wit, P. J. G. M. 1998. Infection-induced expression of the avirulence gene
Avr 9 in transgenic $C f 9$ tomato plants confers resistance to fungal pathogen attack. ICPP98 Congress, Edinburgh.

Tai, T. H., Dahlbeck, D., Clark, E. T., Gajiwala, P., Pasion, R., Whalen, M., Stall, R. E., and Staskawicz, B. J. 1999. Expression of the Bs2 pepper gene confers resistance to bacterial spot disease of tomato. Proc. Natl. Acad. Sci. USA 96:14153-14158.

Van den Ackerveken, G. F. J. M., Van Kan, J. A. L., and De Wit, P. J. G. M. 1992. Molecular analysis of the avirulence gene Avr9 of the fungal tomato pathogen Cladosporium fulvum fully supports the gene-forgene hypothesis. Plant J. 2:359-366.

Van den Ackerveken, G. F. J. M., Vossen, P., and De Wit, P. J. G. M. 1993. The Avr9 race specific elicitor of Cladosporium fulvum is processed by endogenous and plant proteases. Plant Physiol. 103:91-96.

Van der Hoorn, R. A. L., Laurent, F., Roth, R., and De Wit, P. J. G. M. 2000. Agroinfiltration is a versatile tool that facilitates comparative analyses of Avr $9 / C f 9$-induced and Avr4/Cf4-induced necrosis. Mol. Plant-Microbe Interact. 13:439-446.

Van Kan, J. A. L., Van den Ackerveken, G. F. J. M., and De Wit, P. J. G. M. 1991. Cloning and characterization of cDNA of avirulence gene avr9 of the fungal pathogen Cladosporium fulvum, causal agent of tomato leaf mold. Mol. Plant-Microbe Interact. 4:52-59.

Wubben, J. P., Lawrence, C. B., and De Wit, P. J. G. M. 1996. Differential induction of chitinases and 1,3- $\beta$-glucanase gene expression in tomato by Cladosporium fulvum and its race-specific elicitors. Physiol. Mol. Plant Pathol. 48:105-116.

Yu, I.-C., Parker, J., and Bent, A. F. 1998. Gene-for-gene disease resistance without the hypersensitive response in Arabidopsis dndl mutant. Proc. Natl. Acad. Sci. USA 95:7819-7824.

Yu, I.-C., Fengler, K. A., Clough, S. J., and Bent, A. F. 2000. Identification of Arabidopsis mutants exhibiting an altered hypersensitive response in gene-for-gene disease resistance. Mol. Plant-Microbe Interact. 13:277-286. 